\title{
Lidia Pauch
}

[Wrocław ]

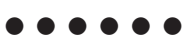

\section{Relacja z Ogólnopolskiej \\ Studencko-Eksperckiej \\ Konferencji Naukowej \\ "Różne Oblicza Historii Mówionej" \\ 29-30 maja 2014 r., \\ Uniwersytet Wrocławski}

Historia mówiona jest metodą, do której wielu historyków ma ambiwalentne podejście. $Z$ jednej strony pozwala odkryć nową jakość historii, z drugiej - pojawia się problem interpretacji subiektywnych relacji oraz wątpliwości związane z metodologią wywiadu. Nie jest to bowiem wbrew pozorom metoda łatwa. Siłą i jednocześnie słabością historii mówionej jest to, że nierzadko trudno jest oddzielić emocje od relacji, którą daje nam rozmówca jako cząstkę swojej osobistej historii. Nieodzowne dla badacza staje się więc nie tylko merytoryczne przygotowanie, lecz także znajomość etycznych reguł i podstawowych zasad, które rządzą ludzką psychiką. Wiąże się z tym również pytanie o rolę historyka, o to jak przeprowadzić badanie jakościowe, nie wchodząc w kompetencje terapeuty, oraz jak zachować równowagę między postrzeganiem rozmówcy jako źródła historii i po prostu - jako człowieka.

Wyżej wymienione problemy są zaledwie częścią dylematów, przed którymi staje badacz decydujący się na wykorzystanie oral history. Dlatego też wydawać by się mogło, że jest to metoda zarezerwowana wyłącznie dla doświadczonych, mogących się pochwalić długim stażem pracowników naukowych. Paradoksalnie jednak historia mówiona pociąga właśnie młodsze pokolenie badaczy, często studentów, którzy dopiero stawiają swoje 
304 pierwsze kroki na polu badań jakościowych. Dla nich oral history jest powiewem świeżości w nauce i szansą na zebranie ciekawszego materiału, który może być wykorzystywany na wiele sposobów. Dzisiaj przecież trudno jest wyobrazić sobie nowoczesne muzeum, które nie używa w swoich projektach i ekspozycjach materiału zebranego metodą wywiadu. Kolejnymi przykładami są tzw. żywe biblioteki i nowe sposoby na popularyzowanie historii, nie tylko pośród uczniów, lecz także w przestrzeni publicznej. W związku z rosnącą popularnością historii mówionej, szerzej - badań narracyjnych, pojawia się potrzeba merytorycznej dyskusji oraz dzielenia się doświadczeniem i przemyśleniami. Dotyczy to zarówno ekspertów z danej dziedziny, jak i młodych badaczy, pragnących skonfrontować swoje świeże refleksje $\mathrm{z}$ autorytetem wieloletniej praktyki.

Stworzenie możliwości do takiej dyskusji było celem, który przyświecał organizatorom Ogólnopolskiej Studencko-Eksperckiej Konferencji Naukowej „Różne Oblicza Historii Mówionej”, która odbyła się w dniach 29-30 maja 2014 r. w Instytucie Historycznym Uniwersytetu Wrocławskiego. Przedsięwzięcie zostało zainicjowane przez członków dwóch kół naukowych - Studenckiego Koła Naukowego Historyków im. Karola Maleczyńskiego i Studenckiego Koła Naukowego „Hatikvah-Nadzieja”. Organizacje te pochodzą z odrębnych jednostek uczelnianych, odpowiednio z Wydziału Nauk Historycznych i Pedagogicznych oraz Wydziału Nauk Społecznych, co zdeterminowało wyjątkowo interdyscyplinarny charakter konferencji. Zadecydował o tym także fakt, iż metoda historii mówionej, choć różnie nazywana, jest coraz częściej wykorzystywana nie tylko przez historyków - jej zalety dostrzegają także psycholodzy, socjolodzy, kulturoznawcy, antropolodzy i etnografowie. Czy jednak wiąże się to z podobnym spojrzeniem na metodologię lub wartość materiału zebranego metodą wywiadu? Pytanie to stało się wiodącym problemem rozważanym $w$ trakcie dyskusji podczas konferencji.

Wydarzenie rozpoczęło się wykładem Prezesa Polskiego Towarzystwa Historii Mówionej, mgra Marcina Jarząbka. Jednym z najważniejszych wątków przemówienia były pytania i ich rola w historii mówionej. Są one narzędziem, które umiejętnie wykorzystywane pozwala naprowadzić rozmówcę na interesujący badacza trop i wydobyć historię z pamięci świadka. Odpowiednio sformułowane pytanie może również ułatwić przełamanie oporu rozmówcy i zdobycie jego zaufania. Świadome korzystanie z pytań jest więc umiejętnością nie do przecenienia. Uczestnicy konferencji mogli czerpać z doświadczenia i wiedzy pana Marcina Jarząbka także podczas specjalnie zorganizowanych warsztatów wprowadzających do metody 
historii mówionej. Tematy, które poruszono w ich trakcie, to m.in. typ idealny wywiadu dla antropologów i historyków oraz rozważenie plusów i minusów metody. Historia mówiona, będąc swoistym połączeniem socjologii, antropologii i historii, jest jednocześnie różnie postrzegana przez te dyscypliny. Dla antropologów tzw. typ idealny wywiadu, to wywiad całkowicie anonimowy, natomiast dla historyków najważniejsza jest możliwość zidentyfikowania świadka - ich typ idealny jest więc całkowicie nieanonimowy. Wiąże się to również z krytyką historii mówionej jako metody subiektywnej, mało wiarygodnej i reprezentatywnej, uniemożliwiającej oddzielenie obrazu zdarzeń wcześniejszych od późniejszych. Jednak jak słusznie zauważył mgr Marcin Jarząbek - tego typu zarzuty mogą dotyczyć w podobnym stopniu innych źródeł, a ponadto niektóre $\mathrm{z}$ nich mogą okazać się w rzeczywistości zaletą. Prezes PTHM zwrócił także uwagę na fakt, że historia mówiona nie służy dokumentacji faktów. Jest to raczej metoda umożliwiająca ukazanie obrazu zdarzeń, który zapisał się w pamięci respondentów.

Podczas konferencji odbyły się też obrady w ramach paneli studencko-doktoranckich, które ujawniły różnice w podejściu do historii mówionej, uzależnione od przyjętej metodologii. Okazało się, że dla jednych metoda ta może być równoznaczna z wywiadem, natomiast dla innych jej istota jest znacznie bardziej skomplikowana. Przyjęcie jednego z tych poglądów ważne implikacje. Jeśli uznamy, że wywiad dotyczący przeszłych zdarzeń jest historią mówioną, tym samym odmawiamy tej metodzie specyfiki. Drugi pogląd wiąże się natomiast $\mathrm{z}$ uznaniem możliwości istnienia indywidualnego wymiaru historii i wartości subiektywnego spojrzenia. Warto zwrócić uwagę, że przyjęcie takiej perspektywy nierzadko zmienia hierarchię faktów, co więcej, ważniejsze od pytania „co było?”, staje się „jak to było i jak wyglądało?". Kolejnym podejściem do historii mówionej jest uznanie jej za metodę pomocniczą, ułatwiającą zrozumienie i interpretowanie archiwaliów. Referaty wygłoszone podczas konferencji dotyczyły różnorodnej tematyki. Dla przykładu można wymienić: Wykorzystanie metodologii historii mówionej w badaniach nad życiem codziennym PRL mgr Anny Adamus, „Poznasz mnie rozmawiajac” - o metodologicznych problemach ,poznawania' przez wywiad na przyktadzie antropologicznych badan terenowych w Kiberze (Kenia) mgr Magdaleny Chułek, czy Narracja autobiograficzna. Wptyw wartości na ksztaltowanie się tożsamości pracowników naukowych uniwersytetu Tobiasza Trawińskiego. Szczególnie ciekawe okazało się skonfrontowanie poglądów na wywiad psychologa i historyka podczas ostatniego 
306 wymienionego wystąpienia. Pojawiło się pytanie o to, czy samo badanie narracyjne może być nazywane historią mówioną, jeśli dotyczy subiektywnej historii osoby, czy też powinno odnosić się do obszerniejszego kontekstu historycznego. Kolejną kwestią, która podzieliła prelegentów (nie tylko psychologów i historyków), był problem zapewnienia anonimowości danych oraz archiwizacji zebranego materiału. Jest to ważki temat, zdaniem uczestników dyskusji wymagający konkretnej regulacji.

Drugiego dnia konferencji studencko-doktoranckiej dyskusję zdominowały natomiast problemy etyczne związane z przeprowadzaniem wywiadu metodą historii mówionej oraz potrzebą odpowiedniego przygotowania badaczy. W swojej pracy osoby wykorzystujące w badaniach metodę oral history stykają się niejednokrotnie z osobami starszymi, świadkami historii, która nie zawsze jest łatwa, potrzebującymi wsparcia i zainteresowania. Problem zaangażowania emocjonalnego $w$ takich sytuacjach wydaje się nieunikniony. Czy badacz, który chce, by jego praca była w miarę możliwości obiektywna, może sobie na takie zaangażowanie pozwolić? Uczestnicy dyskusji odpowiedzieli twierdząco na to pytanie. Co więcej, zwrócili uwagę na konieczność utrzymywania dłuższego kontaktu ze świadkami historii, którzy tego potrzebują. W związku z tym dylematem pojawił się również istotny i warty zauważenia postulat utworzenia kodeksu zasad etycznych historii mówionej. Należy zauważyć, że propozycja ta wychodzi od właśnie młodych badaczy zajmujących się metodą historii mówionej. Świadczy to nie tylko o rosnącej w nowym pokoleniu naukowców popularności oral history, lecz także o metodologicznej dojrzałości i dążeniu do utwierdzenia pozycji metody pośród innych narzędzi badawczych humanistów.

W ramach konferencji odbyły się również prezentacje projektów instytucji wykorzystujących historię mówioną w swoich projektach. Swoją szeroko zakrojoną działalność zaprezentował Ośrodek „Pamięć i Przyszłość”, zajmujący się m.in. zbieraniem relacji świadków powojennej historii Dolnego Śląska, tworzeniem ekspozycji i projektów edukacyjnych. Kolejną instytucją biorącą udział w wydarzeniu było Centrum Dokumentacji Zsyłek, Wypędzeń i Przesiedleń Uniwersytetu Pedagogicznego z Krakowa, które zbiera relacje Sybiraków i osób przymusowo wysiedlonych przez niemieckiego okupanta w czasie II wojny światowej. Centrum prowadzi również działalność edukacyjną. Wyjątkowo interesującą inicjatywą jest zbieranie relacji Sybiraków-Afrykańczyków, którzy w 1942 r., na mocy Układu Sikorski-Majski, wydostali się z ZSRR i w drodze do Polski osiedlili się na Czarnym Lądzie. 
Wykorzystanie historii mówionej w edukacji było zaś tematem wystąpienia wrocławskiego Centrum Inicjatyw UNESCO, które zaprezentowało swój wieloletni projekt „Obojętność Boli”. Ma on na celu rozpowszechnianie wiedzy na temat Sprawiedliwych wśród Narodów Świata i Holokaustu. Projekt skierowany jest zarówno do uczniów, którzy mają okazję porozmawiać ze świadkiem historii, jak i do nauczycieli, dla których Centrum Inicjatyw UNESCO stworzyło specjalny podręcznik warsztatowy.

W konferencji wzięło udział także warszawskie Muzeum Historii Żydów Polskich, przedstawiając projekt „Polscy Sprawiedliwi - Przywracanie Pamięci". Obejmuje on dokumentację relacji dotyczących pomocy Żydom przez Polaków podczas II wojny światowej oraz liczne programy edukacyjne skierowane do młodzieży, w tym polsko-izraelskie wymiany.

Uczestnicy wydarzenia mogli poznać również działalność Yiddish Book Center (Amherst), reprezentowanego przez mgr Agnieszkę Ilwicką. Instytucja ta zajmuje się zbieraniem relacji dotyczących języka jidysz. Szczególnie interesujące w przypadku projektów tej instytucji jest to, że zainteresowanie badaczy nie dotyczy jedynie osób, które ze względu na swoje pochodzenie posługują się tym językiem. Dawcą historii może być każdy, dla kogo jest on z różnych powodów istotny. Wywiady, nagrane oczywiście $\mathrm{w}$ jidysz i opatrzone angielskimi napisami, są dostępne na stronie internetowej: www.yiddishbookcenter.org.

Wartą zauważenia i kontynuowania inicjatywą podjętą przez organizatorów konferencji była organizacja panelu dyskusyjnego z udziałem ekspertów z różnych dziedzin stosujących badania narracyjne. W dyskusji moderowanej przez dra Wojciecha Kucharskiego wzięli udział: dr hab. Małgorzata Ruchniewicz (Instytut Historyczny UWr.), dr Bogna Bartosz (Instytut Psychologii UWr.), dr Julita Makaro (Instytut Socjologii UWr.), dr hab. Jarosław Syrnyk (Katedra Etnologii i Antropologii Kulturowej UWr., IPN Wrocław) oraz dr Piotr Jakub Fereński (Instytut Kulturoznawstwa UWr.). Spotkanie było próbą wypracowania wspólnego stanowiska co do miejsca historii mówionej w badaniach naukowych. Podstawowe różnice między stanowiskami panelistów dotyczyły poglądów na wartość danych zebranych tą metodą. Dr hab. Małgorzata Ruchniewicz jako reprezentantka historii skłaniała się raczej ku uznaniu źródeł historii mówionej jako pomocniczych w badaniach. Metoda ta miałaby być raczej uzupełnieniem pomagającym $w$ interpretacji faktów, szczególnie w badaniu tzw. białych plam w dziejach. Natomiast sam materiał zebrany podczas wywiadu nie powinien być uważany za całkowicie pewne i rzetelne źródło historyczne. 
308 Ponadto dr hab. Małgorzata Ruchniewicz zwróciła uwagę na niedostatki podejścia teoretycznego do historii mówionej w samej historii.

Socjolodzy, reprezentowani przez dr Julitę Makaro, patrzą na tę sprawę zgoła inaczej. Samo pojęcie oral history jest niestosowane. Jej odpowiednikiem jest natomiast metoda biograficzna, zwana inaczej polską. Socjologów ją stosujących interesują pogłębione wypowiedzi dotyczące historii życia respondenta, jej fragmentów, czy też węzłowych momentów. Jak zauważyła dr Julita Makaro, dzisiaj sztuka epistolarna, stanowiąca do tej pory istotny materiał do badań socjologicznych, w zasadzie zanika. W związku z niemożnością korzystania z pamiętników, dzienników czy listów, metoda musiała ewoluować. Dane pamiętnikarskie zostały zastąpione materiałem ze swobodnych wywiadów, które są transkrybowane. Co do wartości danych zebranych tą metodą - subiektywne i obiektywne znaczenia rzeczywistości są stawiane przez socjologów na równi. To, co twierdzi respondent jest więc nie mniej interesujące niż fakty.

Podobne stanowisko przyjmują psycholodzy, których przedstawicielką w dyskusji była dr Bogna Bartosz. Od lat 8o. XX w. status badań jakościowych w psychologii stale się umacnia. Coraz częściej metoda wywiadu nie tylko uzupełnia dane ilościowe, ale staje się autonomicznym narzędziem dającym wymierne efekty. Zdaniem dr Bogny Bartosz żadna, nawet najbardziej wyrafinowana teoria nie potrafi do końca wyjaśnić doświadczenia. Stąd też bierze się idea, by zaczać badanie od drugiej strony i wyprowadzać twierdzenia z indywidualnych opowieści. Badania narracyjne są jednak często krytykowane w psychologii za dużą rolę subiektywnego podejścia badacza w interpretacji danych. Rozwiązaniem tego problemu jest korzystanie z tzw. sędziów kompetentnych czy też weryfikacja wyników z samą osobą badaną. Warto zwrócić uwagę, że odwrotnie niż historia, socjologia i psychologia stawiają na pierwszym miejscu materiał dostarczony poprzez osobę badaną - faktom przydzielając rolę pomocniczą przy ewentualnym porównywaniu materiału.

Dr hab. Jarosław Syrnyk zwrócił natomiast uwagę na długie dzieje historii mówionej. Oral history jest w tym wypadku metodą eklektyczną, znaną od dawna, a ostatnio modną. Jego zdaniem, jest to jedna z pierwotnych metod badawczych. Co więcej, w gruncie rzeczy wszystkie dziedziny humanistyczne dążą do zbadania tego samego, co prawda stosując inne nazewnictwo. Istotna jest przy tym świadomość tego, co jest celem badania. Antropolodzy szukają w wywiadzie odpowiedzi nie tylko na pytanie, dlaczego coś zostało wypowiedziane. Ważne jest również to, kto jest twórcą opowieści. Dr hab. Jarosław Syrnyk postuluje również wprowadzenie prak- 
tycznej interdyscyplinarności w badaniach, oznaczającej konsultowanie materiału z ekspertami z różnych dyscyplin badawczych.

Kulturoznawstwo, posiadając silne założenia filozoficzne, jak twierdzi dr Piotr Jakub Fereński, ma słabo rozwinięte podejście do badań empirycznych. Przekłada się to na interdyscyplinarne sposoby zbierania danych, a co za tym idzie - docenianie wartości historii mówionej. Kulturoznawcy korzystają z niej w badaniach nad pamięcią, która ma odzwierciedlać zmiany zachodzące w kulturze. Przy czym pojawiają się pewne dylematy związane $\mathrm{z}$ rozróżnieniem oral history od history telling. Podobną do historii mówionej metodą, stosowaną również przez socjologów, jest fotowywoływanie.

Pomimo odmiennych perspektyw na wartość danych zebranych tą metodą, paneliści zgodzili się co do pewnych zasadniczych kwestii. Mianowicie wywiad, niezależnie od dziedziny przyjętej przez badacza, jest przede wszystkim spotkaniem z człowiekiem. Świadomość tego faktu jest niezwykle istotna, dlatego że dając niepowtarzalną jakość, spotkanie to jednocześnie składa na barkach badacza odpowiedzialność za rozmówcę. Wiąże się to również ze sposobem wykorzystania i przechowywania danych w odpowiednich archiwach, co niestety często jest zaniedbywane. Jednym z istotniejszych wniosków z dyskusji jest zwrócenie uwagi na to, iż czynnikiem łączącym nowe nurty badań w poszczególnych dziedzinach humanistycznych jest powrót do jakości. Człowiek, jego historia i wytwory nie dają się sprowadzić do faktów i liczb. Ponownie więc nabiera znaczenia stwierdzenie, że całość nie jest jedynie prostą sumą części.

Pozytywny oddźwięk, z jakim spotkała się Ogólnopolska Studencko-Ekspercka Konferencja Naukowa „Różne Oblicza Historii Mówionej”, jest niewątpliwie zachętą do kontynuowania dyskusji na temat miejsca tej metody w badaniach naukowych. Oral history posiada ogromny potencjał, wart rozwijania przez nowe pokolenie badaczy. Proces ten nie może się jednak odbywać bez udziału ekspertów. Badacze decydujący się na wykorzystanie historii mówionej muszą mieć świadomość, że pojawiające się problemy etyczne nie mogą pozostać nierozwiązane. Jest to podstawowy warunek wartości materiału zebranego metodą wywiadu oraz samej historii mówionej. 